\title{
Religiusitas dalam Kumpulan Puisi Rekah Lembah Karya Mudji Sutrisno
}

\author{
Laura Andri R.M. \\ Fakultas Ilmu Budaya, Universitas Diponegoro \\ lauraandrirm@yahoo.co.id
}

\begin{abstract}
Poetry is not only seen from the structure. More than that, poetry is one of the means to convey messages to the public. This study examines the meaning of religiosity of the poems collection of Rekah Lembah by Mudji Sutrisno. The poems in the book have religious themes or are related to divinity and faith. Therefore, research is carried out with a review of themes to determine aspects of religiosity. The method used is descriptive qualitative method. So that finally an interpretation can be found that will produce interpretations in understanding the religious meaning as a whole.The meaning of religiosity contained in the collection of Rekah Lembah poetry by Mudji Sutrisno is: (1) religiosity between humans and God; (2) religiosity among fellow humans; and (4) human religiosity with him.

Keywords: Religiosity, poems, Mudji Sutrisno.
\end{abstract}

\section{Intisari}

Puisi tidak hanya dilihat dari strukturnya saja. Lebih dari itu, puisi adalah salah satu sarana untuk menyampaikan pesan kepada publik. Penelitian ini meneliti makna religiusitas koleksi puisi Rekah Lembah oleh Mudji Sutrisno. Puisi-puisi dalam buku ini memiliki tema-tema keagamaan atau terkait dengan keilahian dan iman. Oleh karena itu, penelitian dilakukan dengan ulasan tema untuk menentukan aspek religiusitas. Metode yang digunakan adalah metode deskriptif kualitatif. Sehingga akhirnya dapat ditemukan interpretasi yang akan menghasilkan interpretasi dalam memahami makna keagamaan secara keseluruhan. Makna religiusitas yang terkandung dalam koleksi puisi Rekah Lembah oleh Mudji Sutrisno adalah: (1) religiositas antara manusia dan Tuhan; (2) religiusitas di antara sesama manusia; dan (4) religiusitas manusia dengannya.

Kata Kunci: Religiusitas, puisi, Mudji Sutrisno.

\section{Pendahuluan}

Karya sastra dan karya seni berada pada kategori yang sama karena memiliki tujuan dan sifat yang sama. Tujuan dari karya seni dan karya sastra adalah membantu manusia menyingkapkan rahasia keadaan, memberi makna pada eksistensi, serta membuka jalan kebenaran.Namun,mereka juga memiliki perbedaan yaitu media bahasa yang digunakan karya sastra untuk menyampaikan pesan pada pembaca. 
Karya sastra merupakan ciptaan yang istimewa, ia tidak sekadar dibaca atau dinikmati, tetapi dapat pula dipelajari melalui analisis tertentu. Menurut Redyanto Noor, sebagai objek empirik, karya sastra harus berdata dan berfakta sehingga dapat dirunut siapapun yang terlibat di dalam ilmu tersebut (2015:7). Makna dari berdata dan berfakta dalam karya sastra lebih mengarah pada gambaran realitas sosial masyarakat yang diangkat sebagai ide atau tema-tema cerita.Karya sastra juga mengungkapkan kehidupan yang luas dan mendalam berisikan cerita kemanusiaan, isyarat keimanan, cinta kasih, kejujuran dan realita.Tidak hanya itu, sastra juga memberi pencerahan (insight) melalui tokoh, peristiwa, persoalan, latar religi, serta budaya. Sastra tidak hanya berbentuk ekspresi estetik tetapi juga berbentuk nilai-nilai tertentu. Nilai-nilai tersebut digunakan untuk membentuk kepribadian yang dewasa dan matang. Sebagai sistem komunikasi estetik, sastra mengandung pesan-pesan moral, salah satunya pesan moral religius. Disadari atau tidak, sastra mampu menjadi pilihan yang dapat digunakan untuk memunculkan nilai-nilai religius dan humanitis dalam masyarakat.

Selain memberikan pengaruh positif, perkembangan budaya di Indonesia juga memberikan pengaruh yang negatif. Hal ini terbukti pada merosotnya pemahaman dan pengamalan nilai religius yang terlihat dari segala aspek termasuk kebahasaan, estetika, dan sistem nilai pada masyarakat. Pada titik permasalahan tersebut, peran sastra sangat diperlukan untuk memperbaiki karakter bangsa dan mencetak masyarakat yang lebih bermoral dan berbudi pekerti luhur.

Sebagai bagian dari karya seni, puisi dapat dianalisis dengan bermacam aspek, baik dari segi struktur maupun segi sejarahnya. Sepanjang zaman, puisi selalu mengalami perubahan dan perkembangan. Menurut Teeuw, hal ini mengingat hakikatnya sebagi karya seni yang selalu terjadi ketegangan antara konvensi dan pembaharuan (1980:12). Puisi merupakan karya yang sangat melibatkan perasaan penyairnya. Perasaan tersebut tidak hanya ditujukan kepada manusia, namun dapat pula ditujukan pada alam semesta dan juga Tuhan. Hal tersebut menjadi bukti bahwa dalam puisi terdapat nilai-nilai keagamaan atau religius. Di sisi lain, religiusitas juga dipandang sebagai pesan atau amanat (message) penyair kepada pembaca. Pesan atau amanat yang dimaksud penyair lebih mengarah pada kodrat dan sifat manusia, tidak pada konsep norma yang dibuat untuk menata dan menilai manusia itu sendiri. 
Menurut Kamus Besar Bahasa Indonesia, religius berarti bersifat religi dan bersifat keagamaan. Religi yang dimaksud lebih mengacu pada percaya pada kekuatan Adikodrati di atas manusia. Sementara religius lebih mengarah pada sikap taat dan patuh pada ajaran agama yang dianut, hubungan batin dan rasa cinta manusia pada Tuhan, serta sikap toleran dan menjalin hubungan baik antara pemeluk agama. Religiusitas memiliki makna yang lebih universal dibandingkan dengan agama. Agama lebih mengacu pada ajaran-ajaran tertentu yang mengartikan bahwa agama bersifat terbatas. Kesadaran religiusitas mengacu pada tiga hal: (1) manusia dengan Tuhan; (2) sesama manusia; dan (3) manusia dengan dirinya.

Oleh karena alasan di ataslah peneliti mengkaji religiusitas dalam kumpulan puisi Rekah Lembah karya Mudji Sutrisno yang dikenal sebagai budayawan Indonesia bernama lengkap Prof. Dr. Fransiskus Xaverius Mudji Sutrisno, SJ. Mudji Sutrisno adalah seorang rohaniawan Katolik yang sudah menghasilkan banyak buku dan religiusitas selalu menjadi tema utama dalam setiap karyanya.

\section{Metode Penelitian}

Penelitian ini menggunakan metode deskriptif kualitatif. Moleong mengatakan dalam bukunya bahwa penelitian kualitatif merupakan penelitian yang mencoba menelaah fenomena yang dialami oleh subjek misalnya perilaku, persepsi, motivasi, tindakan, dan lain-lain secara holistik, dan dengan cara deskripsi dalam bentuk kata-kata dan bahasa (2007:6).

Selain itu, penelitian ini lebih mengarah pada studi kepustakaan atau library reseach dengan sumber utama kumpulan puisi Rekah Lembah karya Mudji Sutrisno (2007). Hal tersebut berkaitan dengan sumber informasi seperti buku-buku, makalah, artikel dan hasil-hasil penelitian yang relevan dengan topik studi ini guna untuk mempertajam hasil kajian.

\section{Hasil dan Pembahasan}

Rekah Lembah merupakan kumpulan puisi yang dibuat Romo Mudji Sutrisno pada tahun 2007. Beliau bertempat tinggal di Jakarta dan berstatus aktif menjadi dosen di Sekolah Tinggi Filsafat Driyarkara, dosen pascasarjana Universitas Indonesia, sertaWakil Pres dan anggota PEN (Perhimpunan Penulis, Novelis, Esais, Penyair Indonesia). Romo Mudji, 
sapaannya, merupakan budayawan dengan sumbangan pemikiran yang menyuarakan peradaban manusia. Rekah lembah sendiri terdiri dari 56 puisi yang terbagi dalam 6 bagian (Yogyakarta, Ibu, Roma, Hening, Gerhana dan Rekah Lembah).

\section{Religiusitas dalam Kumpulan Puisi Rekah Lembah karya Mudji Sutrisno}

Religiusitas kumpulan puisi Rekah Lembah dalam penelitian ini terbagi dalam tiga hal, yaitu: 1) religiusitas antara manusia dengan Tuhan; 2) religiusitas antar sesama manusia; 3) religiusitas manusia dengan dirinya.

\section{Religiusitas antara Manusia dengan Tuhan}

Religiusitas manusia dengan Tuhan dapat berupa doa-doa yang dipanjatkan manusia saat beribadah. Doa-doa tersebut adalah ungkapan rasa syukur dan sadar diri atas peran Tuhan sebagai pencipta alam semesta dalam kehidupannya. Hal ini dapat dilihat dalam kutipan berikut:

lalu sapaMu menepuk bahu pelan menyadarkan hidup berasal dari $\mathrm{Mu}$ berada di tanganMu sang Maha Seniman

\section{("Di Depan Kematian”)}

Kutipan lalu sapaMu menepuk bahu/pelan menyadarkan menunjukkan bahwa Tuhan sebagai sumber eksistensi manusia yang utama sekaligus sebagai sumber inspirasi nilai yang tinggi. Kutipan tersebut juga menjelaskan bahwa manusia juga disadarkan sebagai representasi dunia wujud yang eksistensinya berasal dari Tuhan. Hidup berasal dariMu/berada di tanganMu merupakan ungkapan bahwa segala hal yang berkaitan dengan manusia berpusat pada Tuhan. Dalam hal ini eksistensi Tuhan bersifat tidak terbatas, sedangkan yang terbatas adalah ciptaan-ciptaan yang ada di dalamnya. Sebagai ciptaan Tuhan, manusia terikat dengan hukum penciptaan yang fundamental. Maksud dari hal tersebut adalah proses yang menyaratkan adanya pencipta, waktu, tujuan, ukuran, serta mekanisme hukum yang bekerja secara otomatis untuk mengatur kehidupannya.

Manusia memiliki kebebasan untuk melakukan banyak hal di dunia. Kebebasan ini diberikan sebagai hadiah karena belas kasih Tuhan pada umat-Nya.Melakukan perbuatan 
baik dan buruk atau memutuskan hal-hal berkaitan dengan kehidupannya adalah bagian dari suatu kebebasan. Namun, segala sesuatu selalu memiliki konsekuensi tersendiri dan berpusat pada Tuhan. Apa yang manusia lakukan di dunia harus dipertangunggjawabkan dalam kehidupan setelah kematian kelak. Dalam kehidupan ini kematian akan menjemput kapan saja sesuai kehendak Tuhan. Hal ini menyadarkan manusia bahwa kehidupan yang dimiliki saat ini adalah anugerah yang seharusnya disyukuri. Sehingga berpedoman pada ajaran-ajaran Tuhan serta kesadaran diri manusia pada-Nya adalah sikap yang tepat untuk memperoleh keselamatan dan kehidupan yang kekal.

Tuhan semesta menghadiahi raya warna mengajari indah dalam beda

\section{(“Alam”)}

Kecintaan Tuhan kepada hambaNya merupakan nilai lebih bagi manusia. Keagungan-Nya merupakan sesuatu yang tidak bisa diukur. Tuhan semesta/menghadiahi/raya warna adalah bukti kecintaan Tuhan pada manusia yang merupakan dasar umat beriman dalam mencintai sesama. Hal tersebut mendorong mereka untuk menghayati devosi Tuhan sebagai Sang Maha Kasih melalui perwujudan cinta Tuhan pada sesama. Bukti kecintaan Tuhan tidak hanya terwujud dalam pengampunan dosa, tetapi juga pemeliharaanNya di setiap waktu. Mengajari indah dalam beda bermakna bahwa manusia diciptakan tidak sama, baik secara fisik, psikis, tingkat spiritual, sosial budaya dan lain sebagainya. Perbedaan diciptakan bukan tanpa alasan karena dalam hal iniTuhan mengajarkan manusia untuk bisa mengasihi sesama bagaimanapun kondisinya. Jika manusia mengasihi Tuhan maka hendaknya mereka juga mampu mengasihi sesama. Kehidupan di alam semesta akan harmonis dan selaras jika manusia mampu hidup bersama, tanpa menjadikan perbedaan sebagai alasan perpecahan dan permusuhan. Rasa kasih dan cinta adalah dasar segala perdamaian.

Lembahmu menidurkanku pulas-puas usap jemariMu menerjang relung hening samadhiku 
Usap jemari mengungkapkan adanya hubungan pribadi yang sangat akrab antara manusia dengan Tuhan. Dalam baris ini digambarkan bahwa Tuhan memiliki karakter penyayang dan lembut, bukti nyata yang terwujud adalah ketika manusia bersedia meluangkan waktu dalam semadi atau sujudnya. Lembahmu menidurkanku pulas-pulas memiliki makna bahwa Tuhan memelihara umat-Nya dan memberikan perlindungan serta rasa aman. Ia tidak pernah menjauh, tetapi manusia yang sering lalai dan menghindar dariNya. Terkadang manusia mulai menyadari akan adanyaTuhan dan menjalin hubungan pribadi dengan-Nya ketika manusia menyadari kebutuhannya akan Tuhan, hal itu terjadi ketika manusia berada dalam tekanan hidupnya. Dalam keadaan tersebut, manusia sungguh-sungguh mengakui bahwa ia adalah orang berdosa sehingga membutuhkan pengampunan dari Tuhan. Memiliki hubungan pribadi dengan Tuhan berarti manusia harus melibatkan Dia dalam kehidupannya sehari-hari.

Uji emas iman

Pelita hidup

Benar

Berkelap kelip

Diterpa angin badai

\section{("Beriman")}

Iman adalah pijakan atas berbagai hal yang manusia cita-citakan serta bukti dari seluruh hal yang tidak mereka lihat. Dalam puisi "Beriman" dikatakan bahwa iman merupakan pedoman hidup karena berisi kebenaran. Dalam baris berkelap-kelip/diterpa angin badai mengartikan banyaknya cobaan serta godaan manusia dalam menjaga imannya. Namun, hal itu tidak menjadi alasan mereka terus berupaya berpegang pada iman dalam kehidupan karena imanlah yang akan menumbuhkan keberanian. Hal itu bisa digambarkan seperti manusia yang mempunyai perasaan gentar dan takut terhadap kematian. Jika manusia tersebut benar-benar beriman, kematian justru menjadi alat pengingat untuk lebih mempersiapkan diri saat bertemu dengan Tuhan.

Selain itu, iman adalah alat pembebas dari konsep penghambaan kepada kekuatan lain selain Tuhan. Kondisi beriman membuat manusia memperteguh keyakinan bahwa hanya Tuhan yang memiliki kekuatan besar yang patut dan layak manusia sembah. Dia adalah satu-satunya Tuhan yang layak di puja tidak ada yang lain. Dengan begitu manusia akan menjadi hamba Tuhan yang senantiasa merasakan kebahagiaan di dunia maupun 
akhirat. Segala rahmat dan anugerah yang Tuhan berikan pada manusia tidak dapat ditahan siapapun.

\section{Religiusitas antar Sesama Manusia}

Dalam religiusitas antar sesama manusia, kedua belah pihak saling memerlukan. Manusia sebagai mahluk sosial tidak bisa hidup tanpa bantuan manusia lain. Mereka bekerjasama, bantu membantu, tolong menolong dan saling menghargai serta menghormati. Untuk menjadi manusia yang baik dari sisi religiustias maka rasa kemanusiaan harus berada pada tingkat paling tinggi.

pasti kau tak saling menikam

tega

demi segenggam gobang

pasti kau bersihi lagi

reruntuhan hati beku

buat menenun cabik-cabik bencana

lantaran

prihatinmu

meruang saat bangun pagi sadar diri!

\section{(“Andai Bencana Ada Peduli")}

Sepenggal kutipan di atas berbicara masalah bencana alam, kemanusiaan dan keprihatinan. Bencana dan manusia saling berbagi dalam kehidupan. Sepanjang manusia ada, bencana juga ada. Alasan Tuhan mengadakan bencana untuk membentuk manusia menuju titik kesempuraan sebagai makhluk ciptaan-Nya. Hal ini dikuatkan ketika mengingat manusia adalah ciptaan-Nya yang memiliki banyak kelebihan seperti berakal, berbudi dan juga memiliki kepedulian pada sesama, tetapi terkadang menyalahgunakan kelebihan tersebut dan berubah menjadi serakah.

Rasa kemanusiaan sangat diperlukan sebagai mahluk sosial, karena manusia tidak dapat hidup tanpa manusia lain. Manusia selalu membutuhkan manusia lainnya. Maka dapat dikatakan bahwa manusia sebagai makhluk sosial karena pada diri mereka ada dorongan dan kebutuhan untuk berhubungan(interaksi) dengan orang lain. Manusia juga tidak akan dapat hidup sebagai manusia jika tidak tinggal di tengah-tengah manusia lainnya.

Ungkapan pasti kau tak saling menikam menunjukkan adanya rasa cinta kasih pada sesama. Baris pasti kau bersihi lagi / reruntuhan hati beku mengarah pada 
keinginan untuk saling memaafkan dan saling mengerti satu sama lain sehingga tidak timbul pertikaian. Kondisi ini menunjukkan adanya keseimbangan posisi antara sesama manusia untuk mewujudkan kehidupan yang harmonis, damai dan tenteram. Rasa keprihatinan dan empati dari sebuah bencana merupakan wujud ungkapan kepedulian manusia pada sesamanya.

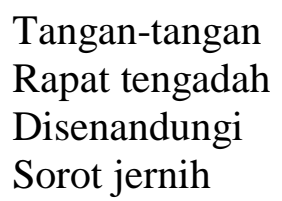

(“Sedekah-kan? Kah?”)

Sepenggal bait di atas bermakna memberi dan pertolongan. Memberi secara finansial atau lebih sering disebut sedekah adalah mendermakan materi pada orang lain yang memerlukan. Hal ini muncul karena adanya dorongan dalam diri manusia sebagai mahluk berjiwa sosial. Merasakan kekurangan dan penderitaan orang lain akan membantu manusia memiliki sifat rendah hati dan suka berbagi. Tangan-tangan / rapat tengadah adalah simbol dari kaum papa yang membutuhkan uluran belas kasih dari sesamanya. Mereka yang memiliki tingkat ekonomi tinggi dengan rela hati membantu sesamanya yang berada pada posisi rendah. Hal ini merupakan upaya untuk menwujudkan keseimbangan dalam kehidupan bermasyarakat.

\section{Religiusitas Manusia dengan Dirinya}

Selain sebagai mahluk sosial, manusia merupakan mahluk pribadi yang mengutamakan kepentingannya sendiri. Manusia mempunyai hak untuk menentukan sikap, pandangan hidup dan perilaku sesuai kemampuannya. Religiusitas manusia dengan dirinya sendiri muncul pada bait berikut

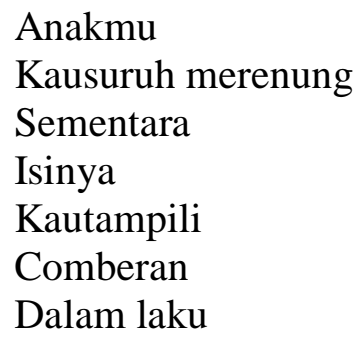


Puisi berjudul "Paradoks" merupakan gambaran manusia sebagai pribadi yang punya hak untuk mengambil keputusan dan menentukan arah hidupnya sendiri. Eksistensinya sebagai manusia kadang menjadi berlebih dan berkembang menjadi perilaku yang egois. Manusia menjadi pusat dari segala sesuatu. Mereka lupa bahwa manusia hidup bersama dengan manusia lainnya. Anakmu Kausuruh merenung/ Sementara/ Isinya/ Kautampili/ Comberan/ Dalam laku memiliki makna bahwa manusia cenderung berorientasi pada diri mereka sendiri. Orang tua cenderung berusaha menguasai, mengekang dan membentuk pribadi anak sepeti yang mereka inginkan. Mereka membungkam hak anak untuk berkembang sehingga sang anak tidak bebas berkembang sesuai keinginannya.

Melalui puisi ini Romo Mudji berusaha menyampaikan pesannya pada pembaca untuk tetap ingat bahwa sebagai mahluk pribadi, manusia tetap berpegang pada prinsip pola perilaku, tidak egois dan menyadari bahwa ada juga pribadi-pribadi lain yang kehadirannya harus dihormati dan dihargai. Masing-masing manusia punya hak untuk menentukan sikap dan tidak ada alasan untuk menguasai dan dikuasai.

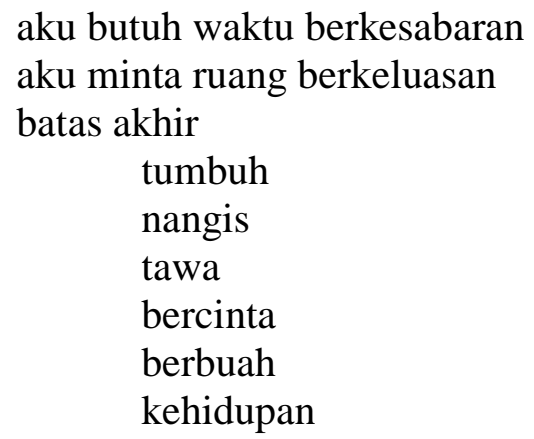

("Proses")

Puisi di atas berisi tentang kebutuhan dasar manusia sebagai mahluk pribadi. Secara pribadi, manusia ditempa dalam sebuah proses kehidupan untuk menjadi manusia kuat dan baik. Hal ini membuat manusia memerlukan ruang dan waktu untuk bereksistensi sebelum lahir menjadi manusia baru, manusia mandiri dengan citra positif. Menangis, tertawa, kebutuhan akan sex serta memiliki keturunan merupakan kebutuhan hakiki setiap manusia. Romo Mudji dalam puisi "Proses" nya mencoba menegaskan bahwa manusia yang berada dalam tingkat akhir pendewasaan diri dalam kehidupan sedang memenuhi kebutuhankebutuhan dirinya.

\section{KESIMPULAN}


Berdasarkan pembahasan di atas,Kumpulan puisi Rekah Lembahkarya Mudji Sutrisno menunjukkan bentuk religiusitas manusia dengan Tuhan, religiusitas antar sesama manusia dan religiusitas manusia dengan pribadinya. Religiusitas sangat diperlukan untuk menjaga kualitas ketaatan terhadap Tuhan dari dimensi yang paling personal. Religiusitas dalam puisi-puisi di atas lebih menitik beratkan pada misi sastra sebagai sarana untuk meningkatkan kualitas kehidupan manusia dan masyarakat. Makna religiusitas yang dominan adalah religiusitas pertama yaitu antara manusia dengan Tuhan. Melalui kumpulan puisi Rekah Lembah ini, Romo Mudji berusaha menyerukan kepada pembaca untuk terus meningkatkan kedekatan diri kepada Sang Pencipta.

\section{Daftar Pustaka}

Faizin dan Agusa Nuryatin. "Religiusitas dalam Syair-Syair Tegalan Karya Imam Chumedi," Seloka:JurnalPendidikan Bahasa dan Sastra Indonesia. Http:/journal.unnes.ac.id/sju/index.php/seloka

Moleong, Lexy J. 2007. Metodologi Penelitian Kualitatif. Bandung: PT Remaja Rosdakarya.

Noor, Redyanto. 2015. Pengantar Pengkajian Sastra. Semarang: Fasindo.

Sutrisno, Mudji. 2007. Rekah Lembah. Jakarta:Hujan Kabisat.

Teeuw. 1980. Sastra dan Ilmu Sastra. Bandung: PT Dunia Pustaka Jaya.

Tresna, Gilang, dkk. "Nilai Religiusitas dalam Tinjauan sajak "Potret Keluarga" Karya WS. Rendra," Parole Jurnal Pendidikan Bahasa dan Sastra Indonesia, vol. 1. 